\title{
A Secondary Research on Human Endocrine Physiology in the Al-Qur'an and the Ahadith
}

Radiah Abdul Ghani ${ }^{1}$, Ahmad Irfan Ikmal Hisham ${ }^{2}$, Athirah Nur Ahmad Rosli ${ }^{1}$

${ }^{1}$ Department of Biomedical Science, Kulliyyah of Allied Health Sciences, International Islamic University Malaysia Kuantan.

${ }^{2}$ Centre of Modern Languages and Human Science, Universiti Malaysia Pahang, Kuala Pahang 26600 Pekan Pahang.

\begin{abstract}
Physiology is one of the remarkable branches in medical field which allows an appreciation of the anatomy as well as the functions of being; which then gives an idea on the purpose of a creation and a better understanding of the purpose of humans themselves. However, modern physiology taught in many Westernised textbooks lack the link and reflection to the worldview of Islam. As a result of this divorce between the modern physiology and the religious worldview, physiology as a subject is lacking "spiritual" connection and thus, produces students with lack of connection with the Tawhidic (Oneness) and admirableness to Allah, much to the dismay of the Islamic teaching. Thus, this paper is aimed to review the relevant scientific knowledge in endocrine physiology and relate it with the Qur'anic verses and Hadith. The roles of melatonin and cortisol that changes between day and night, the role of touch and the release of oxytocin are explained from the Islamic perspective based on the relevant Qur'anic verses and/or the Ahadith. Future research in integrating the physiology with the evidence from the Qur'an and the Ahadith should be attempted by medical and biomedical scientists alike, to further enhance and develop the concept of physiology as a subject in medical schools, not limited to the physical sciences per se, but also the spiritual and metaphysical dimensions.
\end{abstract}

KEYWORDS: Islamic perspective, endocrine system, physiology, melatonin, cortisol, oxytocin

\section{INTRODUCTION}

The alteration of endocrine system in various conditions is the most remarkable changes recorded in human physiology. The physiological function of this system is integrated with other systems in human body such as cardiovascular, nervous, digestive, hepatobiliary system and so forth. Today, tremendous of research in endocrine physiology has been explored and one of the main focus is on the endocrine alteration due to many pathophysiological conditions. ${ }^{1}$ The endocrine physiology is documented as one of the compulsory subject to be enrolled by future doctors and healthcare professional. ${ }^{2}$

With regard to the context of education in Malaysia, most of the scientific knowledge has been translated from the Western perspective. ${ }^{3}$ Current knowledge does not reflect the worldview of Islam and such system produces individual with little concern towards remembrance of Allah. ${ }^{4}$ To overcome this limitation, the Muslim scholars have advocated the concept of Islamization of human knowledge $(\mathrm{IOHK}) .^{5}$ This concept refers to the process of

Corresponding author:

Radiah Abdul Ghani,

Department of Biomedical Science, Kulliyyah of Allied Health Sciences, International Islamic University Malaysia, Jalan Sultan Ahmad Shah, 25200 Kuantan Email: radiah@iium.edu.my examining the existing knowledge which is transmitted from Western, and integrate the Islamic values in the content of knowledge. This concept had been implemented in Nigeria where the content of secular syllabus is integrated with Islamic perspective and therefore the students will be able to analyse the knowledge and relate with Quran and Hadiths. ${ }^{6}$

Searching for scientific data from the Holy Quran is not a new trend as recent study on the Holy Quran arises in tandem with modern scientific investigation. ${ }^{4}$ The investigation of human physiology and traditions of the Prophet Muhammad (PBUH) started in the 8th century and continued to the current era for the welfare of the whole world. However the documentation is still not centralized and therefore, the aim of this study is to identify the verses in Holy Qur'an and Hadith which are related to selected scope of human endocrine system.

\section{METHODOLOGY}

The Holy Qur'an was the primary source of this study. The Holy book consists of 114 chapters and 6666 verses. We studied the Holy Qur'an thoroughly and the chapters and verses were only chosen if they are related to the scope of human physiology. Hadith, collection of narrations concerning the words and deeds of the Prophet Muhammad (PBUH) which is authentic was selected in relevance with the selected scope of physiology. 
The claims of scientific knowledge in selected scope of physiology were vindicated using evidence available in the journals and books. Journal articles were searched in the following electronic databases:PubMed (http://www.ncbi.nml.nih.gov/ pubmed), Science Direct (http://www. sciendirect. com) , Scopus (http://webofknowledge.com) and Google Scholar (http://scholar.google.com.my) and some non-impact journals. The searching was using specific terms and represent selected aspect of the endocrine system to find the updates which is relevant with the Quranic verses or Hadith. The articles chosen were restricted to those in the English Language.

\section{RESULT AND DISCUSSION}

Hormones and between the day and night Melatonin and the darkness

"And He it is Who makes the night as a robe for you, and sleep as repose, and makes the day (as it were) a resurrection". (Surah al-Furqan, 25: 47)

This Quranic verse states that the event of the changes between day and night, has been acknowledged by Allah (SWT) to have significant advantages for human. The creation of night is meant to give time for sleep and rest, while the presence of the day is designed for activities or in other words to make a living. It has been found that human body systems shows significant changes to conform to the day and night, and the normal significant changes is governed by the release of a hormone namely melatonin and cortisol. 7

Melatonin is an indoleamine molecule derived from the essential amino acid tryptophan that is detected widely throughout nature. The rise of melatonin during dark nights acts as a biological timing signal that is driven internally by the activity of a central pacemaker in the suprachiasmatic nuclei of the anterior hypothalamus. Melatonin also the most stable and reliable peripheral biomarker of the timing of the central biological clock. As the period of the melatonin surge indicates the length of the biological night, the pineal gland not only plays a role as a clock, but also as a calendar by providing an organism with information pertaining to seasonal changes in day length. Usually, melatonin is known as the chemical expression or hormone of darkness ${ }^{8}$. During the daytime, the levels of melatonin are barely detectable. ${ }^{7}$

Even though melatonin is well known with its properties as a circadian rhythm transducer, there are several other functions for this molecule have been discovered during the last decade. It has direct free radical scavenging activity and has potential as a disease-preventing agent ${ }^{9}$. Basically when the cells are exposed to oxidative stress, the expression of antioxidant enzymes increase to protect them from damage. Melatonin has been found to regulate antioxidant function in the central nervous system ${ }^{10}$ and against some degenerative neurological conditions. ${ }^{11}$ In an experimental model of Parkinson disease, low doses of melatonin $(10-7 \mu \mathrm{M})$ induced protection against cell death due to neurotoxin. ${ }^{12}$ This study also proved that melatonin has a role to maintain the expression of three antioxidant enzymes, GSH-Px, CuZnSOD and MnSOD which highly expressed under cellular stress condition. The activities of melatonin provide the scientific evidence of benefit of sleep.

"It is out of His Mercy that He has made for you Night and Day,- that ye may rest therein, and that ye may seek of his Grace; - and in order that ye may be grateful" (Surah al-Qasas, 28: 73)

The finding on the importance of darkness of night for sleeping has revealed that human body systems are created to be harmony and aligned with the changes between the day and night. Any disruptions in forms of any sorts of light in the darkness will affect the normal physiology of melatonin release, which may induce many harmful effects to our health. Amazingly, the guideline to sleep in a total darkness has been long before practiced and taught by Prophet Muhammad (PBUH) as mentioned in the Hadith:

Ibn 'Umar reported that the Prophet (PBUH) said, "Do not leave fire burning in your houses when you sleep." (agreed upon) (Riyad-us-saliheen, Chapter 300, no 1652)

Jabir reported that the Messenger of Allah(PBUH) said,

"Cover up containers and tie up water-skins. Lock the door and put out the lamp. Shaytan does not open up a water-container, open a door nor remove a cover. If one of you can find nothing except a piece of food to place over his container together with mentioning Allah's name, he should do that. A mouse can set a house alight around its inhabitants." (Muslim) (Riyad-us-saliheen, Chapter 300, no 1654)

The principle of melatonin release in the dark has been observed in cases of endocrine changes among night shift workers. Thus research had been done to assist this group of workers to have proper hormone changes according to exposure to light. In an experiment demonstrated by Horowitz et al in 2001, it is suggested that the circadian adaptation to night work is best achieved by combining bright light during the night shift and scheduled sleep in darkness during the day. The bright light and room light were exposed to 40 participants during night shift for 4 day and 3 nights. During the day they were scheduled to sleep at home in darkened bedrooms. The melatonin rhythm was observed and it is suggested that scheduling of sleep in the dark play a major role, and it is recommended as a part of prescription for overcoming shift work-related phase misalignment. ${ }^{13}$ In addition, a constant routine for over three weeks revealed significant shifts in the time of peak melatonin expression and realignment of the circadian rhythm. While the smaller phase shift when the time is lesser than 
three weeks showed incomplete adaptation to the shift schedule. It can be concluded that, a careful control of light and darkness pattern exposure for minimum three weeks is crucial for the adaptation of endocrine physiological rhythms among night shift workers. ${ }^{14}$

\section{Melatonin in human milk}

The conformity between the level of melatonin with the changes of the day and night is not only marked by the level of melatonin in the blood circulation. Interestingly, it has been shown that the composition of melatonin in the human milk also vary according to the day and night. Besides contains proteins, fats and carbohydrates, breast milk also contains minerals, vitamins, hormones and enzymes that provide nourishments for the baby and regulate many metabolic processes that include digestion. It was recently found that the levels of components in human milk changes throughout a 24 hours period to adapt to the needs of infants. ${ }^{15}$ Melatonin and the nucleotide 5'AMP works synergistically to regulate circadian rhythms. The level of melatonin and 5'AMP in the human milk is identified to be high during the night and lessened towards pre-dawn. As the function of melatonin and 5'AMP is to induce sleep, it can be understood that the high content of melatonin and 5'AMP during the night is to induce sleep and calming effects for baby. Meanwhile, the low level of melatonin and 5'AMP in the morning is to act as natural stimulants to the baby. ${ }^{16}$

\section{Cortisol Awakening Response}

Cortisol is a hormone secreted from adrenal glands according to diurnal cycles which increase after awakening; a phenomenon termed the cortisol awakening response (CAR). ${ }^{17}$ Cortisol is most actively being secreted during the day, begins with the highest concentrations in the early morning and reduced to the lowest by about midnight. The normal level of cortisol secretion occurs during the diurnal cycle which means the cortisol levels vary in the 24-hour day. In addition to this normal circadian rhythm, the secretion of cortisol can increase due to any stressful event either physical or psychological. ${ }_{18}$ Cortisol has an important role to ensure a continuous supply of energy in order for the body to face and withstand strong external pressure and load. Hence, the main function of cortisol is to prepare and to protect the body from stress. Imbalance of cortisol level in the body will decrease the strength of body system to defend from both internal and external pressure. ${ }^{17}$

A person who has deficiency of cortisol and has an impaired cortisol rhythm shows imbalance of body metabolism. Proof-of-concept studies using synthetic cortisol named hydrocortisone infusions suggest that the biochemical control and life quality may improve due to the possibility the level of this drug to replicate cortisol circadian rhythm. ${ }^{19}$ This finding strengthened the important roles of cortisol which reflects by the event of interchange between day and night. A well-known verse says,

"And among his signs is your sleep by night and by day and your seeking of His bounty, verily in that are signs for those who hearken" [Ar-rum 30:23].

Therefore, it is clearly define from scientific studies and its relation to why Islam stresses the importance on the daily pattern of light and darkness and considers the cycle of night and day as a mercy from Allāh (SWT) as mentioned in the Holy Qur'an,

"Say: See ye? If Allāh were to make the Night perpetual over you to the Day of Judgment, what God is there other than Allahh, who can give you enlightenment? Will ye not then hearken? Say: See ye? If Allah were to make the Day perpetual over you to the Day of Judgment, what God is there other than Allāh, who can give you a Night in which ye can rest? Will ye not then see? It is out of His Mercy that He has made for you Night and Day, that ye may rest therein, and that ye may seek of His Grace - and in order that ye may be grateful" [Al Qasas- 28.71-73].

\section{Affectionate Touch Promotes Bonding through Hormonal Release}

Islam is acknowledged by Allah to bring Rahmah or mercy to the whole mankind. The essence of Islam is clear, to cultivate and spread love and brotherhood throughout the world. Everything created to live in this world deserves to be treated with love and mercy. Hence, as a way to express love and ukhuwwah, the beloved Prophet Muhammad (PBUH) has highlighted the importance of affectionate touch among humankind through his wisdom sayings and his own daily practice. Prophet Muhammad (PBUH) has showed that it is a noble act and practice to hug, kiss or to show any sorts of supportive touch towards family members, children, companions, among Muslims and non-Muslims and animals. This can be clearly understood by appreciating the value mentioned in the Hadiths by Imam Bukhari:

Jarir ibn 'Abdullah reported that the Messenger of Allah said, "If someone does not show mercy to people, Allah will not show mercy to him." (Agreed upon) (Riyad-us-Saliheen, Chapter 27, no 227)

'A'isha said, "Some of the Bedouins came to the Messenger of Allah, may Allah bless him and grant him peace, and said, 'Do you really kiss your children?' He said, 'Yes.' They said, 'But, by Allah, we do not!' The Messenger of Allah, may Allah bless him and grant him peace, said, 'There is nothing I can do if Allah has removed mercy from your hearts!'' (Agreed upon) (Riyad-us-Saliheen, Chapter 27, no 226)

Abu Hurayra said, "The Prophet, may Allah bless him and grant him peace, kissed al-Hasan ibn 'Ali while al-Aqra' ibn Habis was with him. Al-Aqra' said, 'I 
have ten children and have never kissed any of them.' The Messenger of Allah, may Allah bless him and grant him peace, looked at him and said, 'Anyone who does not show mercy will not be shown mercy." (Agreed upon) (Riyad-us-Saliheen, Chapter 27, no 225)

The strengthening of this social bond interestingly can be explained through a number of scientific studies which revealed that the bonding is actually the effects from hormonal release, namely oxytocin which can also be known as brain chemical. It is proposed that oxytocin is an essential integrating factor in the mediation of calm and connection. At first, it was regarded as a female hormone due to its crucial role in labour and lactation. However, the effect of oxytocin is much wider than thought earlier and it is released in broader range of conditions in both male and female. ${ }^{20}$

Oxytocin is secreted by the posterior pituitary gland and stimulated by neurons projections from the hypothalamus, triggering physiological reactions in the body. It is a neuropeptide that can influence neurotransmission. ${ }^{21}$ Oxytocin has the function to stimulate various interactive behaviors that include maternal, sexual, and other social behaviour. Furthermore, it creates bonding between mother and infants and between males and females. Besides that, it may cause sedative effects and elevate pain threshold. It is unique that it may include all the effects of calm and connection response, cause long term effects, and is stimulated to be released by non-noxious stimulation or simply regarded as affectionate touch such as hug, kiss or holding hands. ${ }^{20}$ Interestingly, oxytocin is found by the scientists to reduce activation of brain circuits involved in fear, increase levels of eye contact, and increase trustworthiness and generosity towards others. ${ }^{22}$ All these effects have make it easier for people to bond and connect to each other.

The mechanism of social bonding by oxytocin through affectionate touch can be further understood with the fact that the release of oxytocin is proven to sharpen social evaluation of others, making angry expression as less friendly and attractive, while making neutral and happy expression more friendly and attractive. ${ }^{2}$ In relation to bonding, the intimacy or affiliation is closely related with the interpretation of others. People show more favorable acceptance of a person whom they perceive as more friendly and vice versa.

Interestingly, several scientific findings revealed that the effects of affectionate touch characterized by oxytocin release, is enhanced when presented together with a happy expression. Based on the study by Ellingsen et.al. It was found that touch was most pleasant when performed with a happy expression and this effect was marked by the largest pupil dilatation in the study. As large pupil sizes are linked with increased attractiveness, and signal increased social interest in others, it is to be noted that both gentle touch and increased level of oxytocin increased pupillary dilatations. Hence, increased pupillary responses in these conditions may reflect a mechanism of social bonding. ${ }^{23}$

\section{CONCLUSION}

Recently, there has been growing of interest in relating science and Islamic perspective even it has been studied for hundreds years. About 1400 years ago, Prophet Muhammad (PBUH) stressed the importance of sleep and the Qur'an and hadith emphasize the important of circadian rhythm. The Qur'an and hadith describe the changes of the day and night reflects the regulation of endocrine system which involves the two key hormones; melatonin and cortisol harmonization. The scientific study on touch and endocrine system also being integrated with Sunnah demonstrated by Prophet Muhammad (PBUH) as a way to build a bonding between families and strengthen the ukhuwwah in community. In addition, the integration of endocrine physiology and its role in other body systems such as cardiovascular and digestive system should be highlighted based on Islamic worldview. It is hoped that by integrating Islamic perspective and scientific knowledge it will become a single source of hidayah, the source of truth for this world and the hereafter.

\section{CONFLICT OF INTEREST: None}

\section{ACKNOWLEDGEMENT}

This paper was partially supported by a grant from the Ministry of Higher Education Malaysia (FRGS13054-0295). We would like to thank the Kulliyyah of Allied Health Sciences and Islamization of Human Knowledge Unit, International Islamic University Malaysia for encouragement to write on Science and Islamic perspective.

\section{REFERENCES}

1. Boulpaep, L\& Boron, W. Medical Physiology. (2nd ed). Philadelphia, PA: Elsevier, 2011.

2. Levy, MN, Koeppen, BM, \& Stanton, BA. Berne and Levy Principles ofPhysiology. (4th ed).Elsevier, 2006.

3. Al-Attas MN. The Concept of Education in Islam; 1980. Available at: http://mef-ca.org/ files/attas-text-final.pdf

4. Razak, MAA Globalization and its Impact on Education and Culture. World Journal of Islamic History and Civilization,2011; 1(1), 59-69.

5. Muhammad Abdullah \& Muhammad Junaid Nadvi. Understanding the Principles of Islamic World-View, The Dialogue,2011; VI (3), 269 289.

6. Lemu, BA (2012, August 7). Religiou Education in Nigeria - A Case Study [Web log post]. Retrieved June 15, 2016, from http: / / madanitimbukti. wordpress. Com /2012/ 08/07/religious-educationinnigeria-a-case-study/

7. Cuesta, $J$ \& Singer, $M$ The stress response and 
the critical illness: A Review. Critical Care Medicine, 2012; 40(12). 3283-3289.

8. National Sleep Foundation. (2014). Melatonin and Sleep. Retrieved from http:// sleepfoundation.org/sleep-topics/melatoninand-sleep/page/

9. Rodriguez C, Mayo JC, Sainz RM, Antolin I, Martin V, Reiter RJ Regulation of antioxidant enzymes: a significant role of melatonin. J Pineal Res. 2004; 36(1),1-9.

10. Cagnoli CM, Atabay C, Kharlamova E, Maney H Melatonin protects neurons from singlet oxygen -induced apoptosis J Pineal Res 1995; 18: 222226

11. Sandyk R, Kay SR The relationship of pineal calcification and melatonin secretion to the pathophysiology of tardive dyskinesia and Tourette's syndrome. Int J Neurosci 1991; 58: 215-247.

12. Mayo JC, Sainz RM, Antolin I et al. Melatonin regulation of antioxidant enzyme gene expression. Cell Mol Life Sci 2002; 59: 17061713.

13. Horowitz TS, Cade BE, Wolfe JM, Czeisler CA Efficacy of bright light and sleep/darkness scheduling in alleviating circadian maladaptation to night work. American Journal of Physiology - Endocrinology and Metabolism. 2001; 281(2), E384-E391

14. James FO, Walker CD, Boivin DB Controlled Exposure to Light and Darkness Realigns the Salivary Cortisol Rhythm in Night Shift Workers. The Journal of Biological and Medical Rhythm Research.21(6),2004; 961-972.

13. Horowitz TS, Cade BE, Wolfe JM, Czeisler CA Efficacy of bright light and sleep/darkness scheduling in alleviating circadian maladaptation to night work. American Journal of Physiology - Endocrinology and Metabolism. 2001; 281(2), E384-E391

14. James FO, Walker CD, Boivin DB Controlled Exposure to Light and Darkness Realigns the Salivary Cortisol Rhythm in Night Shift Workers. The Journal of Biological and Medical Rhythm Research. 2004;21(6), 961-972.

15. Andrews, J (2014). Breast Milk's Composition Changes Throughout the Day: Day Milk vs. Night Milk. Retrieved from http:// babycarejournals.com/1506/breast-milkscomposition-changes-throughoutday\#sthash.jfz16XIC.dpuf

16. Sánchez, CL, Cubero, J, Sánchez, J, et al.The possible role of human milk as sleep inducers. Nutritional Neuroscience, 2009; 12 (1), 2-8.

17. Fries $E$, Dettenborn $L$ and Kirschbaum $C$ The cortisol awakening response (CAR): Facts and future directions. International Journal of psychophysiology. 72(1), 2009; 67-73.

18. Ackermann S, Hartmann F, Papassotiropoulos A, de Quervain D JF. And Rasch B Associations between Basal Cortisol Levels and Memory Retrieval in Healthy Young Individuals. Journal of Cognitive Neuroscience, 2013; 25(11), 18961907
19. Chan S \& Debono M. Review: Replication of cortisol circadian rhythm : new advances in hydrocortisone replacement therapy. Ther Adv Endocrinol Metab.2010; 1(3): 129-138.

20. Uvnas-Moberg, K, Ingemar, A \& David, M The Psychobiology of Emotion: The Role of the Oxytocinergic System. International Journal of Behavioral Mechanicine,2005; 12 (2), 59- 65

21. Bethelem, RAI, Honk, JV, Auyeung, B, \& BaronCohen, $\mathrm{S}$ Oxytocin, brain physiology, and functional connectivity: A review of intranasal oxytocin fMRI studies.

Psychoneuroendocrinology, 2013; 38 (7), 962974

22. Grohol, J (2012) Treating Depression with the Oxytocin, the Love Hormone. Retrieved from http://psychcentral.com/news/2012/02/20/ treating-depression-with-the-oxytocin-the-lovehormone/35027.html

23. Ellingsen, DM, Wessberg, J, Chelnokova, O, Olausson, H, Laeng, B, \& Leknes, S (2013). In touch with your emotions: Oxytocin and touch change social impressions while others' facial expression can alter touch. Retrieved from http://www.sv. uio.no/ psi/ english/people/aca/sirigra/ellingsen_oxytocin_ pnec2013.pdf

24. Hafiz Abu Tahir Zubayr 'Ali Za'il (Ed.). (2007). English Translation of Jami' at-Tirmidhi (Vols. 1-6). (Abu Khaliyl, Trans.). Riyadh, KSA: Darussalam.

25. Muhammad Muhsin Khan (Trans.). (1997). The Translation of the Meanings of Sahih al-Bukhari (Vol 5). Riyadh, KSA: Darussalam.

26. As-Sayyid Sabiq. (n.d.). Translation of Fiqh-usSunnah. Retrieved from http:// islamfuture . files.wordpress. com/2009/ 11 /fiqh-ussunnah-five-volumes.pdf 
